\title{
A Comparative Study of Death Anxiety Levels and Reflections among University Students
}

\author{
Çağla Atmaca ${ }^{1}$ \\ Pamukkale University
}

${ }^{1}$ Assoc.Prof.Dr., Pamukkale University, Faculty of Education, English Language Teaching Department, 20070, Denizli, Turkey. Email: catmaca@pau.edu.tr.

Corresponding author:

Çağla Atmaca

E-mail:

catmaca@pau.edu.tr

eISSN: 2458-9675

Received: 19.09.2021

Revision: 12.10.2021

Accepted: 15.10.2021

(C) Copyright 2021

by Author(s)

\begin{abstract}
This concurrent mixed-method research study aimed to validate the psychometric properties of Templer Death Anxiety Scale (TDAS) and compare death anxiety reflections of 332 university students at English Language Teaching (ELT) and English Language and Literature (ELL) departments at a state university in Turkey. The data were collected through the TDAS and semi-structured interviews. According to statistical results, the four-factor model of TDAS was confirmed in this study. Also, department and gender were associated with differences among the participants. In light of phenomenological analyses of the interviews, both ELT and ELL students mostly defined death as a state such as infinity, darkness, inception, endlessness, salvation, freedom, annihilation, uncertainty, and eternity. As for the symbols, the ELT participants used events like traffic accident, sudden death, flying, voyage to symbolise death whereas the ELL participants used some states like innocence, freedom, emptiness, coldness, darkness, loneliness to symbolise death. The results offer a new perspective for death anxiety research in terms of including a different group of participants and highlighting changing attitudes of ELL and ELT students towards death and death anxiety. Educational implications are also discussed.

Keywords:
\end{abstract}

Death anxiety, death attitudes, death education, pre-service teacher education, university students.

\section{Üniversite Öğrencilerinin Ölüm Kaygısı Düzeyleri ve Yansımaları Üzerine Karşılaştırmalı Bir Çalışma}

\section{Öz}

Eş zamanlı karma yöntemle yürütülen bu çalışma, Templer Ölüm Kaygısı Ölçeği'nin psikometrik özelliklerini doğrulamayı ve Türkiye'deki bir devlet üniversitesinde İngiliz Dili Eğitimi ve İngiliz Dili ve Edebiyatı bölümlerinde eğitim gören 332 üniversite öğrencisinin ölüm kaygısı yansımalarını karşılaştırmayı amaçlamıştır. Veriler, Templer Ölüm Kaygısı Ölçeği ve yarı yapılandırılmış görüşmeler yoluyla toplanmıştır. İstatistiksel sonuçlara göre, bu çalışmada Templer Ölüm Kaygısı Ölçeği'nin dört faktörlï modeli doğrulanmıştır. Ayrıca bölüm ve cinsiyet unsurları katılımcılar arasındaki farklılıklarla ilişkilendirilmiştir. Görüşmelerin fenomonolojik analizleri ışığında, her iki bölümde eğitim gören öğrenciler ölümü çoğunlukla sonsuzluk, karanlık, başlangıç, kurtuluş, özgürlük, yok olma, belirsizlik gibi bir durum olarak tanımlamışlardır. Semboller konusunda ise, İngiliz Dili Eğitimi bölümüi öğrencileri ölümü simgelemek için trafik kazası, ani ölüm, uçma, yolculuk gibi olayları kullanırken İngiliz Dili ve Edebiyatı bölüimü öğrencileri ölümüi simgelemek için masumiyet, özgürlük, boşluk, soğukluk, karanlık, yalnızlık gibi durumları kullanmışlardır. Araştırma sonuçları, farklı bir katılımcı grubunu inceleme ve iki farklı bölümdeki öğrencilerinin ölüm ve ölüm kaygısına yönelik değişen tutumlarını vurgulama açısından ölüm kaygısı araştırmaları için yeni bir bakış açısı sunmaktadır. Eğitsel uygulamalar ayrıca tartışılmaktadır.

Anahtar Kelimeler:

Ölüm kaygısı, ölüm tutumları, ölüm eğitimi, hizmet öncesi öğretmen eğitimi, üniversite öğrencileri.

Citation: Atmaca, C.. (2021). A comparative study of death anxiety levels and reflections among university students. Spiritual Psychology and Counseling, 6, 109-131. https://dx.doi.org/10.37898/spc.2021.6.3.156 
Death anxiety is defined as a conscious or unconscious psychological state because of a defence mechanism which could emerge when individuals feel threatened by death (Kesebir, 2014). In his existential view of death, Becker (1973) indicated that death anxiety is a real and basic fear which has an important role in many other forms of anxiety and phobia. Thus, death anxiety is an important trait of health anxiety and may influence other anxiety disorders as well (Furer \& Walker, 2008). Since death triggers fear and anxiety due to the nonexistence in this world (Heidegger, 1962), death anxiety is a negative emotional reaction caused by this nonexistence status of the self (Tomer \& Eliason, 1996).

Although death anxiety is a common phenomenon in all societies (Zhang et al., 2019), it is a multi-faceted concept deriving from different disciplines and has a unique meaning for each individual, society, religion and country. For this purpose, various demographic features have been studied for their effect on attitudes towards death and dying. To exemplify, Russac et al. (2007) examined the influence of age and gender on death anxiety among adults. They found that death anxiety reached peak for both male and female participants during their 20s and there was a sharp decline after this period. However, only for the female participants, there was a second peak period for death anxiety during their 50s. In another study, Bakan and Karadag-Arli (2018) compared death-related attitudes of students receiving either nursing education or religious education at a university in Turkey and concluded that for both groups, death-related education in the departments was not sufficient for them to gain more awareness about death. Besides, there were not statistically significant differences between the two groups in terms of their attitudes towards death.

In line with the relevant literature, there are two starting points for the current study. First, according to Sarıkaya and Baloğlu (2016), various self-report instruments have been employed for assessing levels of death anxiety, however, suitability of factor structures of these instruments has not been investigated in Turkish context thoroughly. Thus, this study aimed to reveal the psychometric properties of English version of Templer Death Anxiety Scale (TDAS) in Turkish setting. Second, what is evident to date is that due to their intense interaction and encounter with dying patients or patients with a terminal illness, health professionals have been under the focus of death anxiety studies. However, since death is a phenomenon which covers all humanity, various professions and groups should be examined to offer a deeper understanding of death across demographic features. Therefore, in this study, university students, namely freshmen and seniors receiving education at the English Language and Literature (ELL) and English Language Teaching (ELT) Departments were chosen for comparative purposes. The reason is that literary works including the theme of death that ELL students encounter, study and present during their higher education appear to outnumber those of ELT students who receive a limited 
instruction upon literary analysis with the theme of death. Besides, the attitudes and knowledge of freshmen and seniors towards the theme of death are likely to display differences due to their changing amount of exposure to literary works including the theme of death. Therefore, to add a new perspective for death anxiety studies, freshmen and seniors at ELL and ELT departments were involved in this concurrent mixed-method research study.

\section{Review of Literature}

The terms of "fear of death" and "death anxiety" have been used interchangeably in the relevant literature; however, "fear of death" is considered to be specific and conscious while "death anxiety" is regarded to be more generalized and subconscious. Death anxiety is related to death acceptance since it will hinder a deeper understanding of death anxiety (Wong, Reker, \& Gesser, 1994). Also, the acceptance of inevitability of death, based on the observations of death of people with a terminal illness, is seen as the last phase of dying because there are denial and isolation, anger, bargaining, depression, and acceptance stages, respectively (Kübler-Ross, 1969).

Relevant literature includes various death anxiety theories. One of the modern theories is terror management theory (TMT) driven by Becker's (1973) existential view of death. In this view, much of people's energy, as a strategy, is said to focus on the denial of death in order to keep death anxiety under control. TMT claims that although people are aware of inevitability of death, they still endeavour for selfpreservation (Pyszczynski, Greenberg, \& Solomon, 1999). In terms of religiosity, in the worldview defence hypothesis of TMT, there is a relationship between religiosity and death anxiety. That is, death anxiety is stated to be at the lowest level among the very religious and irreligious people while it is at the highest level among uncertain people, which leads to the assumption that the level of death anxiety decreases in line with the increase in religiosity or vice versa (Greenberg et al., 1990). Another theory is Posttraumatic Growth Theory (PTG) which highlights that experiencing a life crisis, specifically death of a beloved one, may ensue positive changes such as attaching more gratitude for life, focusing more on internal goals, and fostering interpersonal relationships (Tedeschi \& Calhoun, 1996, 2004).

To cope with death anxiety, individuals can be given specific education, like endof-life care education which is delivered for creating a more open communication to reduce death anxiety and improve attitudes towards dying patients. To evaluate the effectiveness and impact of such end-of-life education courses, health care professionals and undergraduate medical students filled out a scale called Multidimensional Fear of Death Scale (MFODS). It was revealed that the participants' overall scores of death fear reduced and that gender, age, and profession of the participants were found to 
be important variables causing changes in the level of fear. Thus, it can be concluded that end-of-life education courses can increase health care workers' awareness and better their attitudes towards dying patients (Hegedus, Zana, \& Szabó, 2008).

Apart from health care professionals, nurses, patients, and older people (AbdelKhalek, 2005; Fortner \& Neimeyer ,1999; Hegedus et al., 2008; Russac et al., 2007; Sharif Nia et al., 2016), children and stakeholder perspectives were also investigated in various educational contexts. In a study, the children were asked to make drawings about death and fill in the Death Concept Questionnaire. Their understanding of death was found to be related to their past experiences in that the participants with a previous death experience were found to possess a more realistic perception regarding death (Bonoti, Leondari, \& Mastora, 2013). As for stakeholder opinions, Mcgovern and Barry (2000) examined Irish parents' and teachers' knowledge and opinions about children's grief and death education at schools. It was found out that the teachers and parents were both in favour of discussing about death with children and integrating death education into existing school curriculum. It was also revealed that teachers should be trained about how to educate children towards death before they encounter it.

University students were also included in death-related studies because their death anxiety is important as it affects their attitudes towards life and their optimism could reduce death anxiety (Azarian, Aghakhani, \& Ashuri, 2016). To illustrate, the perceptions of freshmen students at Psychology Department from Haifa University were examined to reveal their opinions about a grieving mother on her daughter's suicide and another mother's grieving after her daughter's death in some other conditions like car accident. The participants regarded the grief of the mother whose daughter committed suicide less severe compared to that of the mother whose daughter died in some other conditions. In addition, the participants previously experiencing a loss regarded the bereaved mother blaming herself to be more suffering and in need of more professional help than the mother not blaming herself (Bar-Nadav, 2002). In a similar vein, Kuwaiti college students filled out various scales on love of life, death anxiety and death depression. The analyses showed that there were no significant gender differences for the love of life scale. However, the female participants were found to have higher levels of death distress compared to their male counterparts (Abdel-Khalek, 2007). Similarly, a cross-sectional study conducted on university students in Tehran revealed that the female students had a higher level of death anxiety compared to the male students and that the married students had a higher level of death anxiety compared to the single students (Khoshi, Nia, \& Torkmandi, 2017). Finally, Ellis, Wahab, and Ratnasingan (2013) investigated college students' perspectives in Malaysia, Turkey and the United States, and concluded that religiosity appeared to be positively correlated with fear of death. In addition, the female participants were 
more religious and feared death more compared to the male students, and the Muslim participants were reported to express far more fear than the Christian participants.

As is seen in the above-mentioned studies, there have been different findings upon the link between demographic features and death anxiety. Therefore, there is still a need for more validated and multidimensional research studies to measure attitudes towards death (Neimeyer, Wittkowski, \& Moser, 2004). In addition, health care professionals, nurses, patients, children and older people (Abdel-Khalek, 2005; Bonoti, Leondari, \& Mastora, 2013, Fortner \& Neimeyer ,1999; Hegedus et al., 2008; Russac et al., 2007; Sharif Nia et al., 2016) were investigated in the relevant literature but university students have attracted the attention of researchers in recent years. Although university students in different departments have been included in some research studies, no body of research has provided a straightforward answer about the perspectives of ELT and ELL students so far. In this context, there still exists a gap in the literature upon death anxiety with regard to the attitudes and reflections among ELT and ELL students. Finally, validation and adaptation studies conducted upon TDAS in different contexts resulted in different findings in terms of its psychometric properties (Sarıkaya \& Baloğlu, 2016), and more research studies are needed to shed light upon the changing construct of the scale in different settings due to contextbound differences. Thus, this study aimed to answer the following research questions:

1. What are the psychometric properties of English version of Templer Death Anxiety Scale (TDAS) in Turkish context?

2. What are the participating ELT and ELL students' death anxiety levels according to the TDAS?

3. Is there a significant difference between ELT and ELL students' death anxiety levels in TDAS in terms of demographic features (gender, age, department, grade)?

4. Is there a difference between ELT and ELL students' written reflections in terms of their definitions and symbols of death?

\section{Methodology}

\section{Research Design}

The first aim of the study was to demonstrate the validity of the death anxiety scale which was developed by Templer (1970) and has been used in a number of studies in different contexts. The second aim was to gain an in-depth understanding about death anxiety levels and death-related reflections of ELL and ELT students through performing comparative analysis. Due to the cross-sectional nature of the study, the purpose was to describe the current status of the phenomenon of death. Therefore, 
various demographic features were examined and the study took place at a single time (Levin, 2006). Freshmen and seniors from both ELL and ELT departments were involved in the study. Templer death anxiety scale (TDAS) with 15 items was employed for gathering quantitative data while a semi-structured interview with two open-ended questions was used for gathering qualitative data. These two data collection tools were included in the same survey and distributed to the participants at the same time in May in 2018. That is to say, the participants first filled out the TDAS and then went on to answer the open-ended questions. In this way, the researcher aimed to benefit from concurrent triangulation via collecting numerical and textual data simultaneously. Thus, a concurrent mixed-method research design was adopted to define relationships among variables more accurately and benefit from the complementary purposes of words and numbers (Creswell et al., 2003; Dörnyei, 2007; McKay, 2006).

Specifically, this study is a cross-sectional study aiming to find out and compare the death anxiety levels and reflections of ELT and ELL students. Thus, no causal linkages are given. Rather, the focus was on examining the frequency distributions of some emerging themes and reveal the associations between some demographic features (Bourque, 2004; Zangirolami-Raimundo, Echeimberg, \& Leone, 2018; Zheng, 2015).

While the quantitative part of study was in the form of validating the scale, the qualitative part of the study was conducted as a phenomenological study. Phenomenological studies, which investigate humans' lived experiences through their descriptions, are one of the commonly employed qualitative research designs. In these studies, perspectives of a number of participants are often gathered via interviews and based on the participants' specific statements, their experiences are described to find what they have in common about the phenomenon in question (Creswell et al., 2007). Furthermore, phenomenological studies can be applied in various settings including educational settings (Yüksel \& Y1ldırım, 2015). In this vein, the current study was conducted at a higher education institution.

\section{Participants}

The participants were BA level university students at a state university in Turkey and they were chosen via convenience sampling (Mackey \& Gass, 2005) in that the researcher contacted the participants who were within easy reach but these participants were chosen according to their department and grade. In total, 332 participants from ELT (N: 161) and ELL (N: 171) Departments participated in the study. There were 237 females and 95 males. They were chosen among the freshmen (N: 213) and seniors (N: 119). Their ages ranged between 18 and 40, and average of age was 21 . 


\section{Data Collection Tools}

In order to collect data, a survey including a scale and semi-structured interview form was administered to the participants. Death Anxiety Scale (TDAS) which was developed by Templer (1970) and has 15 items, was used in this study in a fivepoint Likert-type format with the anchors 1 (I completely disagree) to 5 (I completely agree). Six items are reverse scored to mitigate response bias, with higher scores reflecting higher death anxiety. Due to its short and simple nature, the participants found it easy to reply in a short time.

TDAS has been employed in various studies in Turkish context (Gedik \& Bahadır, 2014; Şenol, 1989). For example, the Turkish translation of the scale was carried out via the back- translation method and internal correlation of the Turkish form as well as the test-retest reliability was confirmed (Ertufan, 2000). In addition, Akça and Köse (2008) performed the reliability and validity of the scale in the Turkish language via factor analysis. The researchers separated 15 items into four factors as cognitive and sensitive, physical changes, time passed, illness and pain, which is similar to the original structure of the scale. However, in current study, English version of TDAS was employed and there were no changes in terms of language and wording since the participants were students at ELT and ELL departments.

As for qualitative data, a semi-structured Written Interview Protocol(WIP) with two open ended questions was used and the findings were subjected to phenomenological analysis procedures. The first question was "How would you define death? Why?" and the second question was "What or who best symbolizes death for you? Why?" Only the seniors were asked open-ended questions since they were considered to be more exposed to literary works including the theme of death via their literary courses, assignments and theoretical/practical in-class presentations. There were 110 ELT freshmen and 51 ELT seniors while there were 103 ELL freshmen and 68 ELL seniors. The similar number of freshmen and seniors provided a sound basis to make comparisons between the two groups. Each participant was given a numerical code to ensure anonymity while exemplifying quotes.

\section{Procedure}

The data in this study were collected face-to-face in that the researcher first contacted the lecturers of the students via email, informed them about the study and made an appointment to conduct the study. Then, the researcher visited the classes, informed the students about the scope of the study and requested them to participate on a voluntary basis. The researcher waited in the classrooms while the participants were filling out the survey in case of any questions or comments. It took approximately 20-25 minutes to fill out the survey. After that, the researcher collected the completed surveys and indicated that they could reach study results on request 
via contacting the researcher with the email address written in the consent form. As for ethical considerations, all procedures performed in this study involving humans were in accordance with the ethical standards of the institution at which the study was conducted. The researcher got the official permission from the Ethical Commission of the state university where the study was conducted. Finally, the participation was on voluntary basis as indicated in the consent form of the data collection tool where all the participants first read the scope and aim of the study, confirmed that they were willing to participate in the study by checking the item "I read the information above and I am willing to take part in the study".

\section{Data Analysis Tools}

The quantitative data were collated using SPSS software to check statistical significance. Then, test of normality was run and the skewness coefficient emerged as -.36, while the kurtosis coefficients emerged as .60. According to Table 1, considering the cut-off value of skewness and kurtosis between -1 and +1 , the assumption of normality was met for the current data. Thus, parametric tests were run for further analyses.

Table 1.

Test of Normality

\begin{tabular}{lccccccccr}
\hline & $\mathrm{N}$ & \multicolumn{1}{c}{ Minimum } & Maximum & Mean & Std. Deviation & \multicolumn{2}{c}{ Skewness } & \multicolumn{2}{c}{ Kurtosis } \\
\cline { 2 - 9 } & Statistic & Statistic & Statistic & Statistic & Statistic & Statistic & Std. Error & Statistic & Std. Error \\
\hline topl & 332 & 19,00 & 73,00 & 48,9910 & 9,34291 &,- 360 &, 134 &, 597 &, 267 \\
Valid N (listwise) & 332 & & & & & & & & \\
\hline
\end{tabular}

Written responses of the participants were subjected to phenomenological analysis procedures. There are various steps in phenomenological research, namely bracketing, intuiting, analysing, and describing. In the bracketing stage, the researcher first identifies what $\mathrm{s} / \mathrm{he}$ expects to find and then intentionally lays these ideas aside to see the experience from the perspective of the participating person who has lived the experience. In the intuiting step, the researcher focuses on the meaning attributed to the phenomenon in the preceding research. In analysing step, to describe the phenomenon, the researcher refers to coding and categorisation. In the describing stage, comprehension and definition of the phenomenon are accomplished (Greening, 2019; Moustakas, 1994).

In line with the steps of phenomenological studies (Moustakas, 1994), first, the researcher identified death anxiety as a phenomenon and aimed to investigate death anxiety from different people's perspectives, namely ELT ad ELL department students at a state university. Then, death anxiety definitions and research studies upon death anxiety were reviewed in the relevant literature and then TDAS and interview were chosen as data collection tools. After that, TDAS and semi-structured interviews were administered to the participants to see their perspectives upon death anxiety based on their own experiences. The participants, apart from filling out TDAS, were asked to 
provide their individual definitions and symbols of death in their own terms according to their previous experiences. Finally, the researcher analysed the textual data gathered via written statements of the participants, identified significant statements and quotes for further exemplification, and combined these statements into categories and themes to write textual descriptions of participants' experiences. In order to increase objectivity of qualitative data analysis, a separate coder from the ELT department with a master degree was also involved in the analyses. The researcher first gave some information to the second coder about the aim and participants of the study and timing of the analysis. In the first round (after the analysis of approximately $25 \%$ of the data) agreement level was found to be .70 while in the second round (when all data were analysed) it increased to .90 (Miles \& Huberman, 1994: 64). Despite the higher level of agreement, both coders held the third meeting to reach total consensus. At the end of the meetings and discussions, the analyses were given their final shape.

\section{Results}

\section{Quantitative Results}

First of all, statistical results of the TDAS will be given to answer the first research question: What are the psychometric properties of English version of Templer Death Anxiety Scale (TDAS) in Turkish context? Similar to Akça and Köse (2008), in this study confirmatory factor analysis produced satisfactory fit indices for four-factor structure of English version of Templer Death Anxiety Scale $(\chi 2(\mathrm{~N}=332)=166.83$, $\mathrm{p}=0.00 ; \chi 2 / \mathrm{df}=1.99 ; \mathrm{GFI}=0.94 ; \mathrm{CFI}=0.92 ; \mathrm{RMSEA}=0.055 ; \mathrm{SRMR}=0.051)$, as

Figure 1.

Confirmatory Factor Analysis Results of TDAS

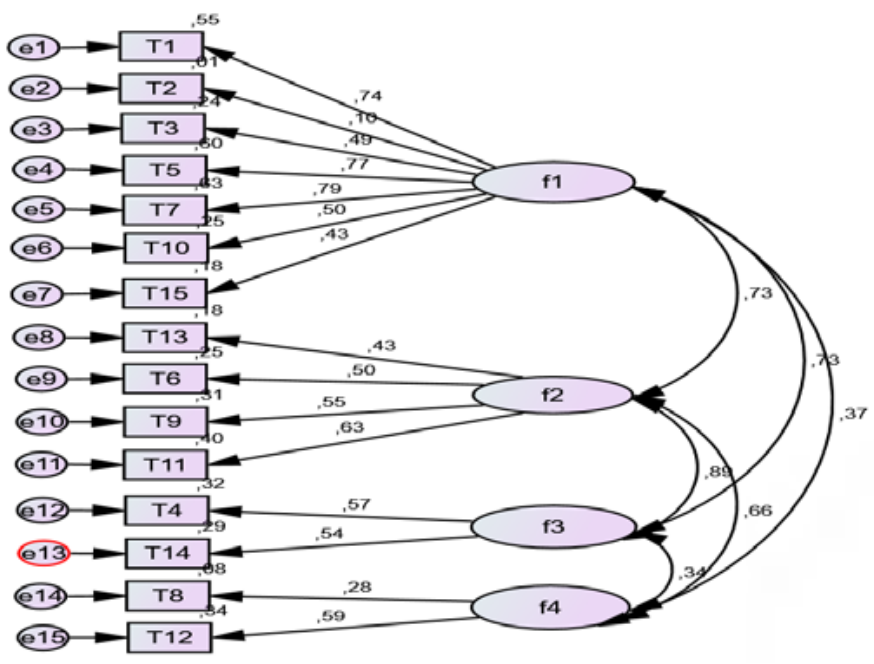


indicated in Figure 1. Although the factor loading of the item 2, which is one of the reverse items, was low in the factor 1 dimension, this item was kept in the scale because of its significant contribution to the explained variance and also possession of sufficient fit index of the scale. In statistical terms, the items with low loadings could be retained at times to meet statistical identification requirements or the minimal number of items per factor. In this regard, the researcher preferred preserving the poorly performing item in the scale since it did not risk the overall fit indices (Hair et al., 2014). Also, internal consistency for the whole scale was at a satisfactory level $(\alpha=.81)$.

As to the second research question (What are the participating ELT and ELL students' death anxiety levels according to the TDAS?), general mean score of the participants was found to be 3.051, which indicates a medium level of death anxiety. As for the third research question (Is there a significant difference between ELT and ELL students' death anxiety levels in terms of demographic features such as gender, age, department and grade?), statistical results for demographic features are given below.

Table 2 .

Tests of Between-subjects Effects

\begin{tabular}{|c|c|c|c|c|c|c|c|c|}
\hline Source & $\begin{array}{c}\text { Type III Sum } \\
\text { of Squares }\end{array}$ & $\mathrm{df}$ & Mean Square & $\mathrm{F}$ & Sig. & $\begin{array}{c}\text { Partial Eta } \\
\text { Squared }\end{array}$ & $\begin{array}{l}\text { Noncent. } \\
\text { Parameter }\end{array}$ & $\begin{array}{c}\text { Observed } \\
\text { Power }^{\mathrm{b}}\end{array}$ \\
\hline Corrected Model & $3.016^{\mathrm{a}}$ & 7 & .431 & 3.938 & .000 & .078 & 27.563 & .983 \\
\hline Intercept & 2188.205 & 1 & 2188.205 & $2.000 \mathrm{E} 4$ & .000 & .984 & 19997.363 & 1.000 \\
\hline department & .460 & 1 & .460 & 4.200 & .041 & .013 & 4.200 & .533 \\
\hline grade & .058 & 1 & .058 & .531 & .467 & .002 & .531 & .112 \\
\hline gender & 2.144 & 1 & 2.144 & 19.598 & .000 & .057 & 19.598 & .993 \\
\hline $\begin{array}{l}\text { department } * \\
\text { grade }\end{array}$ & .428 & 1 & .428 & 3.912 & .049 & .012 & 3.912 & .505 \\
\hline $\begin{array}{l}\text { department } * \\
\text { gender }\end{array}$ & .593 & 1 & .593 & 5.418 & .021 & .016 & 5.418 & .641 \\
\hline grade $*$ gender & .184 & 1 & .184 & 1.679 & .196 & .005 & 1.679 & .253 \\
\hline $\begin{array}{l}\text { department } * \\
\text { grade } * \text { gender }\end{array}$ & .233 & 1 & .233 & 2.129 & .145 & .007 & 2.129 & .307 \\
\hline
\end{tabular}

As the data attest in Table 2, there are statistically significant differences between the participants in terms of their department $(p=0.41)$ and gender $(p=0.000)$ with regard to their death anxiety levels. Thus, null hypothesis was rejected. However, no significant differences were observed $(p=0.467)$ in terms of their grades. When we look at the interactions of the demographic variables, significant correlations were found between the interaction of the variables of department-grade $(p=0.049)$ and department-gender $(p=0.021)$ in terms of death anxiety levels. However, there were no significant correlations between the interactions of grade-gender $(p=$ $0.196)$ or department, grade and gender $(\mathrm{p}=0.145)$ with regard to death anxiety levels. In addition, the data signalled that the mean score of the ELT participants $(\overline{\mathrm{X}}: 3.006)$ is lower than that of the ELL participants $(\overline{\mathrm{X}}: 3.095)$, which indicates 
that the ELT students have a slightly lower level of death anxiety compared to the ELL students. The general mean score of the freshmen participants $(\overline{\mathrm{X}}: 3.066)$ is higher than that of the senior participants $(\overline{\mathrm{X}}: 3.035)$, which signals that the freshmen have a slightly higher level of death anxiety compared to the seniors. Finally, the general mean score of the female participants $(\overline{\mathrm{X}}: 3.146)$ is higher than that of the male participants ( $\overline{\mathrm{X}}: 2.955)$, which reveals that the female participants have a higher level of death anxiety compared to the male participants.

Table 3.

Department-grade Estimates

\begin{tabular}{lccccc}
\hline & & & Lower Bound & Upper Bound \\
\multirow{2}{*}{ ELT } & freshmen & 3.065 & .035 & 2.996 & 3.134 \\
& senior & 2.948 & .052 & 2.846 & 3.050 \\
\hline \multirow{2}{*}{ ELL } & freshmen & 3.068 & .034 & 3.000 & 3.136 \\
& senior & 3.122 & .048 & 3.027 & 3.217 \\
\hline
\end{tabular}

Table 4.

Department-grade Pairwise Comparisons

\begin{tabular}{|c|c|c|c|c|c|c|c|}
\hline \multirow[b]{2}{*}{ department } & \multirow[b]{2}{*}{ (I) grade } & \multirow[b]{2}{*}{$(\mathrm{J})$ grade } & \multirow{2}{*}{$\begin{array}{c}\text { Mean } \\
\text { Difference } \\
(\mathrm{I}-\mathrm{J})\end{array}$} & \multirow[b]{2}{*}{ Std. Error } & \multirow[b]{2}{*}{ Sig. ${ }^{a}$} & \multicolumn{2}{|c|}{$\begin{array}{l}95 \% \text { Confidence Interval for } \\
\text { Difference }^{\mathrm{a}}\end{array}$} \\
\hline & & & & & & Lower Bound & Upper Bound \\
\hline \multirow{2}{*}{ ELT } & freshmen & senior & .117 & .063 & .063 & -.006 & .240 \\
\hline & senior & freshmen & -.117 & .063 & .063 & -.240 & .006 \\
\hline \multirow{2}{*}{ ELL } & freshmen & senior & -.054 & .059 & .365 & -.171 & .063 \\
\hline & senior & freshmen & .054 & .059 & .365 & -.063 & .171 \\
\hline
\end{tabular}

Table 5.

Department-gender Univariate Tests

\begin{tabular}{|c|c|c|c|c|c|c|c|c|c|}
\hline \multicolumn{2}{|c|}{ department } & $\begin{array}{l}\text { Sum of } \\
\text { Squares }\end{array}$ & $\mathrm{df}$ & $\begin{array}{l}\text { Mean } \\
\text { Square }\end{array}$ & $\mathrm{F}$ & Sig. & $\begin{array}{c}\text { Partial Eta } \\
\text { Squared }\end{array}$ & $\begin{array}{l}\text { Noncent. } \\
\text { Parameter }\end{array}$ & $\begin{array}{c}\text { Observed } \\
\text { Power }^{\mathrm{a}}\end{array}$ \\
\hline \multirow{2}{*}{ ELT } & Contrast & .380 & 1 & .380 & 3.476 & .063 & .011 & 3.476 & .460 \\
\hline & Error & 35.454 & 324 & .109 & & & & & \\
\hline \multirow{2}{*}{ ELL } & Contrast & .090 & 1 & .090 & .825 & .365 & .003 & .825 & .148 \\
\hline & Error & 35.454 & 324 & .109 & & & & & \\
\hline
\end{tabular}

According to Table 3, the mean score of the ELT freshmen ( $\overline{\mathrm{X}}: 3.065)$ is close to that of the ELL freshmen ( $\overline{\mathrm{X}}: 3.068)$. However, the mean score of the ELT seniors $(\overline{\mathrm{X}}: 2.948)$ is lower than that of the ELL seniors ( $\overline{\mathrm{X}}: 3.122)$. In this regard, the level of death anxiety appears to be similar for the freshmen whereas the ELT seniors were found to have a lower level death anxiety compared to the ELL seniors. In addition, while the ELT seniors have a lower level of death anxiety ( $\mathrm{X}: 2.948)$ compared to the ELT freshmen ( $\overline{\mathrm{X}}: 3.065)$, the ELL freshmen have a lower level of death anxiety $(\overline{\mathrm{X}}: 3.068)$ compared to the ELL seniors ( $\overline{\mathrm{X}}: 3.122)$. However, according to Table 4 and Table 5 , these in-group differences were not statistically significant. 
Table 6.

Department-gender Estimates

\begin{tabular}{llllcc}
\hline & & & & Lower Bound & Upper Bound \\
\hline ELT & female & 3.152 & .033 & 3.087 & 3.217 \\
& male & 2.861 & .053 & 2.756 & 2.965 \\
\hline \multirow{2}{*}{ ELL } & female & 3.140 & .030 & 3.080 & 3.200 \\
& male & 3.050 & .051 & 2.949 & 3.150 \\
\hline
\end{tabular}

Table 7.

Department-gender Pairwise Comparisons

\begin{tabular}{|c|c|c|c|c|c|c|c|}
\hline \multirow[b]{2}{*}{ department } & \multirow{2}{*}{$\begin{array}{l}\text { (I) } \\
\text { gender }\end{array}$} & \multirow{2}{*}{$\begin{array}{l}(\mathrm{J}) \\
\text { gender }\end{array}$} & \multirow{2}{*}{$\begin{array}{c}\text { Mean } \\
\text { Difference (I-J) }\end{array}$} & \multirow[b]{2}{*}{ Std. Error } & \multirow[b]{2}{*}{ Sig. ${ }^{a}$} & \multicolumn{2}{|c|}{$\begin{array}{c}\text { 95\% Confidence Interval for } \\
\text { Difference }^{\mathrm{a}}\end{array}$} \\
\hline & & & & & & Lower Bound & Upper Bound \\
\hline \multirow[t]{2}{*}{ ELT } & female & male & $.291^{*}$ & .063 & .000 & .168 & .415 \\
\hline & male & female & $-.291^{*}$ & .063 & .000 & -.415 & -.168 \\
\hline \multirow[t]{2}{*}{ ELL } & female & male & .091 & .059 & .128 & -.026 & .207 \\
\hline & male & female & -.091 & .059 & .128 & -.207 & .026 \\
\hline
\end{tabular}

Table 8 .

Department-gender Univariate Tests

\begin{tabular}{llcccccccc}
\hline \multirow{2}{*}{ department } & $\begin{array}{c}\text { Sum of } \\
\text { Squares }\end{array}$ & df & $\begin{array}{c}\text { Mean } \\
\text { Square }\end{array}$ & F & Sig. & $\begin{array}{c}\text { Partial Eta } \\
\text { Squared }\end{array}$ & $\begin{array}{c}\text { Noncent. } \\
\text { Parameter }\end{array}$ & $\begin{array}{c}\text { Observed } \\
\text { Power }^{\mathrm{a}}\end{array}$ \\
\hline \multirow{2}{*}{ ELT } & Contrast & 2.370 & 1 & 2.370 & 21.654 & .000 & .063 & 21.654 & .996 \\
& Error & 35.454 & 324 & .109 & & & & & .331 \\
\hline \multirow{2}{*}{ ELL } & Contrast & .255 & 1 & .255 & 2.328 & .128 & .007 & 2.328 & \\
& Error & 35.454 & 324 & .109 & & & & &. \\
\hline
\end{tabular}

Tables 6,7 and 8 show the interaction of the department-gender variables with regard to death anxiety levels of the participants. Male students in both departments were found to have a lower level of death anxiety compared to their female counterparts. However, this difference is significant $(p=.000$, at 0.05 level) for the ELT department, with lower mean score of male students $(\overline{\mathrm{X}}: 2.861)$ compared to their female counterparts $(\overline{\mathrm{X}}: 3.152)$ but mean score of the ELL male students $(\overline{\mathrm{X}}: 3.050)$ is closer to that of their female counterparts $(\overline{\mathrm{X}}: 3.140)$.

\section{Qualitative Results}

The written responses will be given in order to answer the last research question: Is there a difference between ELT and ELL students' written reflections in terms of their definitions and symbols of death? The participants were free to write more than one answer for both questions. The participants came up with different death definitions and symbols. The emerging themes and categories were formed based on the participants' written comments. Thus, some participant quotations are given to exemplify the emerging theme and support the tabular findings. 
Table 9.

ELT Definitions of Death

\begin{tabular}{ll}
\hline Emerging Themes & Categories \\
\hline State & infinity, darkness, inception, endlessness, salvation \\
Event & losing everything, finishing, separating from family \\
Nature & natural cycle, process of life, natural \\
Object & door, discharge paper \\
Place & transfer station \\
Colour & black \\
Faith & faith \\
Illness & hearth attack \\
\hline
\end{tabular}

According to Table 9, eight themes emerged. Some of the ELT seniors' responses are offered below to exemplify the emerging themes about their death definitions. The number represents the order of participation in coding.

111: It is a natural process of life and we should admit this end of life. Death is not horrifying but dying makes me think of my family. I look at the death issue in terms of inevitable parts of human being because they are born and they die. I just don't want to get a disease such as cancer.

111 defines death as natural, end of life and inevitable. Although death is not considered horrifying, it reminds him/her the family issue and s/he does not want to die of cancer. Here death is seen as an ordinary part of living and it is not treated as a phenomenon to be afraid of. This quotation exemplifies the nature theme in that death is found in human nature and we cannot escape from it. What draws attention is the fear of getting cancer, which might result from the participant's unfavourable past experiences.

129: It is the end of life, reality. Instead of believing in heaven and hell, I try to turn this world into heaven. I don't live it for the possible other life. I live it for today. Who believes in God turns this life into hell.

129 defines death as the end of life and reality, and states that s/he tries to turn this mortal world into heaven rather than believing in the heaven or hell. This quotation exemplifies the state theme since the participant approaches death as reality. In addition, s/he does not seem to be religious and adopts a critical stance towards believers. Finally, s/he tends to appreciate living the moment and getting the most out of it rather than waiting for another possible world. In sum, this participant seems to be free of religious beliefs and in favour of personal efforts to achieve happiness.

Now, ELT participants' reflections upon death symbols will be provided in the following table and quotations. 
Table 10.

ELT Symbols of Death

\begin{tabular}{ll}
\hline Emerging Themes & Categories \\
\hline Event & traffic accident, sudden death, flying, voyage, war \\
Place & graveyard, cemetery, a brilliant garden, hospitals \\
Nature & leaf, snow, fall season \\
Object & door, tomb, weapon, knife, white dress \\
Colour & grey, white, black \\
State & darkness, absence, end, ambiguity \\
Illness & cancer \\
People & Atatürk, grandfather, dying people \\
Faith & life after death \\
\hline
\end{tabular}

According to Table 10, nine themes emerged. As one of the participants indicates:

112: I think seasons symbolise death best. In each season, trees or plants and even lands die and stop giving gifts. Thus, we can see death and reborn when we look at the nature.

This quotation exemplifies the nature theme with the season category because 112 associates death with the seasons in the nature and makes a link between the way the nature revives and goes silent in different periods throughout a year and the way human beings are born, live and go silence after death. In the same way the nature changes colour, appearance and temperature in different seasons, a human being goes through changes in terms of appearance in their lifetime from birth to death.

115: I fear car crash and it reminds me death when I see an accident anywhere. And another symbol is war. Many people die in wars.

This quotation exemplifies the event theme with the traffic accident and war categories because 115 thinks that car crash and war symbolise death as many people die in both events. Such a reflection might have resulted from personal experiences or exposure to accident and war events in different resources such as seeing traffic accident scenes or battlefields on TV channels or in newspapers. As these events can cause some people to lose their lives, they are likely to be associated with death.

132: I don't know why I think so but white colour and looking at the sky under the trees reminds me death.

Different colours such as grey, white and black were used to symbolise death and this quotation exemplifies the colour theme. For 132, the colour of white and looking at the sky when $\mathrm{s} /$ he is under the trees symbolise death although the participant is not totally sure about the underlying reason behind such a symbol. Maybe it is because the body of the deceased is covered with a white shroud before the burial ceremony in some funerals or as the expression says "Sky is the limit", in other words, the sky seems endless with no limitations. Alternatively, sky is far away, like the feelings that death evokes among some people. 
Now, ELL participants' reflections upon death definitions and symbols will be demonstrated in the following tables and quotations.

Table 11.

ELL Definitions of Death

\begin{tabular}{ll}
\hline Emerging Themes & Categories \\
\hline State & salvation, freedom, annihilation, uncertainty, eternity, darkness \\
Event & travelling, changing dimension, sleeping, escaping, rebirth \\
Nature & natural occurrence, leaf, very cold \\
Object & closed box \\
People & enemy \\
Place & end of the road \\
\hline
\end{tabular}

According to Table 11, six themes emerged. Some of the ELL seniors' responses are illustrated below.

266: Death means salvation, freedom, to me. Everything and everyone is going to die and disappear one day. We should not worry about it because death will catch us sooner or later. Thanks to death, we will leave all these worthless, worldly problems behind. We can't take it with us when we die.

This comment exemplifies the state theme because 266 defines death as salvation, freedom and takes it as natural and inevitable since it will happen to everybody. $\mathrm{S} /$ he does not seem to be worried about death as it will happen to all people one day. $\mathrm{S} / \mathrm{he}$ also touches on the compulsory side of leaving all the mortal issues behind and escaping from the worldly problems after death. In this sense, $\mathrm{s} /$ he appears to possess the escape acceptance of death. Such a comment signals general acceptance of the phenomenon and also hints about obstacles people may experience in their lives temporarily. Here mortality and religious beliefs in afterlife come to the fore.

285: Death is a closed box. When we open this box, we cannot know what to do, we come across. Maybe we can come across the flower garden or we can come across with the fire garden. It changes according to your life that you are living.

This quotation represents the object theme since 285 sees death as a closed box in that people do not know what is inside the box. In other words, they do not know what will happen after death. Death can be a good or bad surprise for the person depending on the life s/he led when $\mathrm{s} /$ he was alive. It is similar to the expression "Life is a box of chocolate." because we do not know what life will bring to us or what will happen to us. Thus, we see what happens as we live our lives. Finally, we are given some clues about belief in afterlife, specifically, belief in the heaven and hell because they are likened to flower garden and fire garden.

315: One word "death" includes many meanings. Death is fear, death is feeling nothing. Death is contradiction. Death is nothing and everything. It is emptiness and fullness, inevitable or new life. "Unknown." 
For 315, death has multiple meanings such as fear, inevitability, obscurity and contradiction like emptiness and fullness. Here we see multi-layered definitions of death, especially contradiction since we can see some antonyms like nothing-everything, empty-full. Death may mean the end of mortal life, beginning of afterlife or obscurity. We are given contrastive sides of death as in juxtaposition which is a literary device used to create a rhetorical effect by highlighting deliberate differences for readers to compare and contrast, and see the relationships between the elements.

Finally, ELL participants' reflections upon death symbols will be clarified in the following table and quotations.

Table 12.

ELL Symbols of Death

\begin{tabular}{ll}
\hline Emerging Themes & Categories \\
\hline State & innocence, freedom, emptiness, coldness, darkness, loneliness \\
Nature & flower, seasons, nature, winter, crows, owls, tree, forest \\
Event & birth, killing, war, global warming, driving too fast \\
People & aunt, grandfather, family, beloved ones, grandmother, men \\
Object & big balloon, marbles, tombstone, shroud \\
Place & graveyard, dark places, narrow places \\
Colour & purple, black \\
Time & time, clock \\
Faith & Muslimism, hell-heaven \\
Illness & illness \\
Literary work & The Godot in waiting for Godot by Jamel Beckett \\
\hline
\end{tabular}

As is seen in Table 12, 11 symbols emerged. Some of the ELL seniors' responses are given below.

269: Life symbolizes death for me. Because, these two contrast subjects are the core of our existence and they symbolise each other at the same time.

314: Death symbolizes darkness and light. For good people, death symbolizes light. For bad people, death symbolizes darkness.

In these two comments, the former symbolises death as a contradictory concept and links it to life, and the latter employs two contrasting concepts such as darkness and light to symbolise death. However, the latter makes a distinction between good and bad people by attributing darkness for bad people and attributing light for good people. In these quotations, death is symbolised as two sides of the same coin. In other words, life and death are both found in the same human being and these two sides come into existence by complementing each other in the same person's mould. Since there are contrastive elements in the same comment, it is again possible to mention the tracks of juxtaposition where two things are placed side by side to highlight their differences. Finally, the latter reminds belief in afterlife because darkness refers to the hell while light refers to the heaven and a clear distinction is made between the good and the bad. 
279: 4 seasons symbolise death for me. In spring, the nature blossoms but in winter all flowers, everything dies. There is a cycle in nature like our lives. We are born, we grow up, and then we die.

Here death is associated with four seasons. Similar to the nature cycles, people are born, live and die. As a part of the nature, people's lifetime reflects different phases of the nature and events in different seasons. When we think about weather conditions, temperature and appearance of the nature in these four seasons, we see differences in each one, and the same is said to go for a human's lifetime. Humans go through physical differences in the course of time, moving from infancy, to childhood, adolescence, young adulthood, adulthood and elderliness. Humans lead a life which is similar to the revival and changes in the nature.

281: Coldness and the colour, purple, symbolise the death for me. Because the colour of dead body is always purple and the body is not warm, it is always cold.

This comment draws attention to the physical features of a dead person by making a comparison between the deceased and coldness and colour of purple. For him/her, the dead body is cold and purple. Here we are given some observable states of death since there is loss of heat and colour change in human body at the point of death. These illustrations may stem from personal experiences of seeing a dead body either as a first-hand experience or as exposure to audio-visual stimuli in mass media.

\section{Discussion and Conclusion}

ELT and ELL students can be introduced to the notion of death during their education because as university students this is important for their goal setting and perspectives about life (Azarian et al., 2016). Based on this need, this concurrent mixed-method research study was conducted to reveal and compare the death anxiety levels and death related reflections of ELL and ELT Department students (freshmen and seniors). This study also aimed to investigate psychometric properties of Templer Death Anxiety Scale (TDAS) which has been densely used in death-related studies and has resulted in different factor analysis findings in different contexts. According to the statistical results, similar to Akça and Köse (2008), in this study confirmatory factor analysis produced satisfactory fit indices for four-factor structure of English version of Templer Death Anxiety Scale $\left(\chi^{2}(\mathrm{~N}=332)=166.83, \mathrm{p}=0.00 ; \chi 2 / \mathrm{df}=\right.$ 1.99; $\mathrm{GFI}=0.94 ; \mathrm{CFI}=0.92 ; \mathrm{RMSEA}=0.055 ; \mathrm{SRMR}=0.051)$.

Overall, the participants were found to have a medium level of death anxiety according to TDAS ( $\overline{\mathrm{X}}: 3.051)$ and this finding might have been affected from their age because the average of age was 21 which is claimed to be the age period when death anxiety level is at the highest level according to Russac et al. (2007). Participants' answers to the scale were further supported in their written comments where they stated death definitions and symbols. When death definitions were compared, it was seen that there were eight themes in the ELT group 
while there were six themes in the ELL group. The number of emerging themes was similar and the most three frequently emerging themes were state, event, and nature in both groups. Despite these similarities, some differences were revealed in the quantitative and qualitative analyses. To begin with, though grade of the participants did not have any significant effect in their death anxiety levels, statistically significant differences were detected between the participants in terms of their department $(\mathrm{p}=0.41)$ and gender $(\mathrm{p}=0.000)$. Specifically, the female participants had a higher level of death anxiety compared to the male participants and the ELT students displayed a slightly lower level of death anxiety compared to the ELL students. When written reflections of the participants upon death definitions and symbols were compared in terms of department, some differences were identified. For instance, in terms of death definitions, there were some differences because there were the themes of colour, faith, and illness in the ELT group, yet these themes were not found in the ELL group. Besides, the theme of people occurred in the ELL group, not in the ELT group. As for the symbols of death, there were nine themes for the ELT group whereas there were 11 themes for the ELL group. In addition, the order of the most commonly occurring themes were different because the most commonly occurring themes were event, place, nature, and object for the ELT group while they were state, nature, event and people for the ELL group. The themes of event, place, nature, object, colour, state, illness, people and faith were common for both groups; however, there were the themes of time and literary work which were found only in the ELL group. These findings can give some clues about the effect of department upon death anxiety attitudes of ELT and ELL students. In addition to their individual differences and past experiences, being exposed to more varied literary works including the theme of death appears to have a say in creating differences in the perceptions of ELL students about definitions and symbols of death and revealing them to possess a slightly higher level of death anxiety compared to ELT students.

This study bears some similarities and differences with the previous literature. To begin with, echoing Furer and Walker (2008), being exposed to various literary works including the themes of death and death anxiety can increase or decrease death anxiety levels of ELT and ELL students and influence their attitudes towards the phenomenon of death. Additionally, the findings of this study support some of the earlier studies by concluding that death anxiety levels display differences according to gender. Similar to Abdel-Khalek (2007), Gedik and Bahadir (2014), and Khoshi, Nia and Torkmandi (2017), the female students were reported to experience a higher level of death anxiety compared to the male students. However, in contrast to Bakan and Karadag-Arli (2018), departmental difference was found to signal important implications for changing attitudes towards death and death anxiety. Additionally, in line with the death attitude profile of Wong, Reker and Gesser (1994), some participants adopted neutral acceptance, some of them adopted approach acceptance while some others adopted escape acceptance mentioning salvation. Last but not least, how death is perceived among ELL and ELT students is reflected in the participant quotations. For example, some were found to believe in afterlife whereas a few of them denied it. Also, two ELL seniors 
used "crows" as symbols of death in their responses while one of the ELL seniors defined death as waiting for someone who will never come, like waiting for Godot. These alternative perspectives of death can be explained by individual differences (DeSpelder \& Strickland, 1996), culture and/or religiosity (Ellis, Wahab, \& Ratnasingan, 2013).

The findings have clear implications beyond the context of the study and raised the question of how university students, specifically ELT and ELL students, can be guided or informed about the concepts of death and death anxiety. To exemplify, they can be directed to some activities like reading literary works, watching appropriate movies, having meetings with experts, holding discussion sessions with the professionals, all of which can be organised by the university administration for personal and professional development. For instance, the university in which this study was conducted sends a formal email to all of the academic and administrative staff when a student, lecturer, an officer or administrator passes away, gives those people's beloved ones their condolences, clearly states the time and place of the funeral, and organises a vehicle for those who would like to participate in the funeral ceremony. Alternatively, the university holds a funeral at the faculty of the deceased, has a short speech upon him/ her, prays and takes him/her to the graveyard together with the crowd there.

Another implication based on the findings of this study is the inclusion of endof-life courses, maybe in the form of elective/compulsory courses for ELT and ELL students. These courses can be delivered by experts and professionals in the field to enhance these students' consciousness about death or dying people in their families or environment (Hegedus et al., 2008). As for pre-service teacher education programs, much in line with Mcgovern and Barry's (2000) suggestion, death education can be integrated into pre-service teacher education curriculum since ELL and ELT department graduates are likely to become English teachers. This will necessitate the inclusion of death-education related courses into curriculum, specifically with a purpose to train psychologically well-equipped teacher candidates.

\section{Strengths and Limitations}

There are a number of caveats that need to be mentioned in the context of this study. First, the English version of Templer Death Anxiety Scale was confirmed to be a valid instrument to investigate death anxiety in Turkish context. Second, this study included participants with a different profile, that is, university students in ELT and ELL departments, rather than health professionals who have been dominant participating groups in the relevant literature. Third, this study reached some striking results via comparative analyses to demonstrate the effect of various demographic features on death anxiety levels and death related reflections of the participants. Finally, the study shed light upon a hidden area in death anxiety studies, namely definitions and symbols of death, with the help of in-depth investigation of the phenomenon via qualitative data analysis procedures. 
However, the current study is limited to some extent. To begin with, focusing on ELL and ELT students was both the starting point and limitation of the study because there were only two groups for comparative purposes. In this study, exposure to literary studies including the theme of death was found to create differences for ELL department participants to display a slightly higher level of death anxiety but in some other contexts and research groups, exposure to such studies might reduce the level of death anxiety. Thus, future studies should be conducted upon participants with different demographic features (such as different departments, ages or professions) to reveal similarities and differences with current study findings. Therefore, further studies in various contexts are needed to examine different participant groups via various data collection tools and statistical procedures to see the long-term effects of specific educational interventions. In other words, in order to draw more in-depth conclusions about causation and to triangulate data, future studies may benefit from longitudinal studies with different data collection tools like questionnaires, observations, diaries, journals and interviews, and adopt structural equation modelling (SEM) or path analysis in their methodology. In light of such studies, ELT and ELL students can be introduced to the notion of death better, provided professional help to cope with their death anxiety and broaden their perspectives about the nature of death, which will facilitate their future personal and professional lives. Both groups of participants in this study are likely to become English teachers. Therefore, it is of great importance for them to be introduced to death concept and coping strategies as a part of their professional development. Whatever the institution or level it is, they will be expected to deal with human beings. Especially these days when the world struggles with the COVID-19 pandemic, death education seems necessary for a more effective participation of various stakeholders.

\section{Author Statement}

This manuscript or a very similar manuscript has not been published, nor is under consideration by any other journal.

\section{Compliance with Ethical Standard}

The author declares that all procedures performed in this study involving humans were in accordance with the ethical standards of the institution at which the study was conducted. The researcher got the official permission from the Ethical Commission of the institution where the study was conducted. Finally, the participation was on voluntary basis as indicated on the data collection tool where all the participants first read the scope and aim of the study, confirmed that they were willing to participate in the study by checking the item "I read the information above and I am willing to take part in the study". 


\section{Funding}

The author declares that there was no funding for the study.

\section{Conflict of Interest}

The author declares that she has no conflict of interest.

\section{References}

Abdel-Khalek, A. M. (2005). Death anxiety in clinical and non-clinical groups. Death Studies, 29, 251-259.

Abdel-Khalek, A. M. (2007). Love of life and death distress: Two separate factors. Journal of Death and Dying, 5(4), 267-78. doi:10.2190/OM.55.4.b.

Akça, F., \& Köse, I. A. (2008). Adaptation of death anxiety scale (DAS), validity and reliability studies. Clinical Psychiatry, 11, 7-16.

Azarian, A., Aghakhani, S., \& Ashuri, A. (2016). Investigating the relationship between death anxiety and attitude towards life among university students. International Journal of Medical Research \& Health Sciences, 5, 233-238.

Bakan, A. B., \& Karadag-Arli, S. (2018). Comparison of attitudes toward death between university students who receive nursing education and who receive religious education. Journal of Religion and Health, O(0), 1-9. doi: 10.1007/s10943-018-0609-z.

Bar-Nadav, O. (2002). Students' attitudes towards death, bereavement and suicide. Unpublished Master's Thesis, Faculty of Social Sciences, University of Haifa, Israel.

Becker, E. (1973). The denial of death. New York: Free Press.

Bonoti, F., Leondari, A., \& Mastora, A. (2013). Exploring children's understanding of death: Through drawings and the death concept questionnaire. Death Studies, 37(1), 47-60. doi: 10.1080/07481187.2011.623216.

Bourque, L. B. (2004). Cross-sectional design. In Michael S. Lewis-Beck, Alan Bryman, and Tim Futing Liao (Eds.), The SAGE encyclopedia of social science research methods, pp. 230. Thousand Oaks: Sage Publications, Inc. doi: https://dx.doi.org/10.4135/9781412950589.

Creswell, J. W., Plano Clark, V. L., Gutmann, M. L., \& Hanson, W. E. (2003). Advanced mixed methods research designs. In A. Tashakkori \& C. Teddlie (Eds.), Handbook of mixed methods in social and behavioral research (pp. 209-240). Thousands Oaks, Calif.: Sage.

Creswell, J. W., Hanson, W. E., Plano Clark V. L., \& Morales, A. (2007). Qualitative research designs: Selection and implementation. The Counseling Psychologist, 35(2), 236-264.

DeSpelder, L. A., \& Strickland, A. L. (1996). The last dance: Encountering death and dying (4 $4^{\text {th }}$ ed.). Mountain View, CA, US: Mayfield Publishing Co.

Dörnyei, Z. (2007). Research methods in applied linguistics. Quantitative, qualitative and mixed methodologies. New York: Oxford University Press.

Ellis, L., Wahab, E. A., \& Ratnasingan, M. (2013). Religiosity and fear of death: A three nation comparison. Mental Health, Religion \& Culture, 16(2), 179-199. doi: 10.1080/13674676.2011.652606. 
Ertufan, H. (2000). Bir grup tıp öğrencisi üzerinde ölüm kaygısı ve korkusu ölçeklerinin geçerlik güvenilirlik çalışması [Validity and reliability study of Templer's Death Anxiety Scale and Collett $\&$ Lester's Fear of Death Scale on a group of students in faculty of medicine]. Unpublished master's thesis, Institute of Graduate Studies in Health Sciences, İstanbul University, İstanbul.

Firestone, R. W. (1984). A concept of the primary fantasy bond: A developmental perspective. Psychotherapy, 21, 218-225.

Fortner, B. V., \& Neimeyer, R. A. (1999). Death anxiety in older adults: A quantitative review. Death Studies, 23(5), 387-411. doi: 10.1080/074811899200920.

Furer, P., \& Walker, J. R. (2008). Death anxiety: A cognitive-behavioral approach. Journal of Cognitive Psychotherapy: An International Quarterly, 22(2), 167-182.

Gedik, Z., \& Bahadır, G. (2014). Evaluation of death anxiety and effecting factors in a Turkish sample. Journal of Human Sciences, 11(2), 388-400.

Greenberg, J., Pyszczynski, T., Solomon, S., Rosenblatt, A., Veeder, M., Kirkland, S., \& Lyon, D. (1990). Evidence for terror management II: The effects of mortality salience on reactions to those who threaten or bolster the cultural worldview. Journal of Personality and Social Psychology, 58, 308-318.

Greening, N. (2019). Phenomenological research methodology. Scientific Research Journal (SCIRJ), $\operatorname{VII}(\mathrm{V}), 88-92$.

Hahn, C. (2008). Doing qualitative research using your computer: A practical guide. London: SAGE Publications Ltd.

Hair, J. F., Black, W. C., Babin, B. J., \& Anderson, R. E. (2014). Multivariate data analysis. New Jersey, NJ: Pearson Prentice Hall.

Hegedus, K., Zana, Á., \& Szabó, G. (2008). Effect of end of life education on medical students' and health care workers' death attitude. Palliative Medicine, 22, 264-269.

Heidegger, M. (1962). Being and time (1. Macquarrie and E. Robinson, Trans.). London: SCM Press LTD. (Original work published 1927).

Kesebir P. (2014). A quiet ego quiets death anxiety: Humility as an existential anxiety buffer. Journal of Personality and Social Psychology, 106(4), 610-23.

Khoshi, A., Nia, H. S., \& Torkmandi, H. (2017). Investigation into the factors affecting death anxiety in Iranian students. Journal of Clinical and Diagnostic Research, 11(12), 24-27.

Kübler-Ross, E. (1969). On death and dying. New York: Macmillan Publishing Co.

Levin, K. A. (2006). Study design III: Cross-sectional studies. Evidence-Based Dentistry, 7, 24-25. doi:10.1038/sj.ebd.6400375.

Mackey, A., \& Gass, S. M. (2005). Second language research: Methodology and design. London: Lawrence Erlbaum Assoc.

Mcgovern, M., \& Barry, M. M. (2000). Death education: Knowledge, attitudes, and perspectives of Irish parents and teachers. Death Studies, 24(4), 325-333. doi: 10.1080/074811800200487.

McKay, S. L. (2006). Researching second language classrooms. Lawrence Erlbaum, Associates Publishers: London.

Miles, M. B., \& Huberman, A. M. (1994). Qualitative data analysis. London: Sage Publication.

Moustakas, C. (1994). Phenomenological research methods. Thousand Oaks, CA: Sage. 
Neimeyer, R. A., Wittkowski, J., \& Moser, R. P. (2004). Psychological research on death attitudes: An overview and evaluation. Death Studies, 28, 309-340. doi: 10.1080/07481180490432324.

Pyszczynski, T., Greenberg, J., \& Solomon, S. (1999). A dual process model of defense against conscious and unconscious death-related thoughts: An extension of terror management theory. Psychological Review, 106(4), 835-845.

Russac, R. J., Gatliff, C., Reece, M., \& Spottswood, D. (2007). Death anxiety across the adult years: An examination of age and gender effects. Death Studies, 31(6), 549-561. doi: 10.1080/07481180701356936.

Sarıkaya,Y., \& Baloğlu, M.(2016). The development and psychometric properties of the Turkish death anxiety scale (TDAS). Death Studies, 40(7), 419-431. doi: 10.1080/07481187.2016.1158752.

Sharif Nia, H., Lehto, R. H., Ebadi, A., \& Peyrovi, H. (2016). Death anxiety among nurses and health care professionals: A review article. International Journal of Community-Based Nursing and Midwifery (IJCBNM), 4(1), 2-10.

Şenol, C. (1989). Ankara ilinde kurumlarda yaşayan yaşlılarda ölüme ilişkin kaygı ve korkular [Anxiety and fear about death among elderly who are residing in institutions in Ankara]. Unpublished master's thesis, Ankara University, Ankara, Turkey.

Tedeschi, R. G., \& Calhoun, L. G. (1996). The Posttraumatic Growth Inventory: Measuring the positive legacy of trauma. Journal of Traumatic Stress, 9(3), 455-471.

Tedeschi, R. G., \& Calhoun, L. G. (2004). Posttraumatic growth: Conceptual foundations and empirical evidence. Psychological Inquiry, 15, 1-18.

Templer, D. I. (1970). The construction and validation of a death anxiety scale. Journal of General Psychology, 82, 165-177.

Tomer, A., \& Eliason, G. (1996). Toward a comprehensive model of death anxiety. Death Studies, 20(4), 343365 .

Wong, P. T. P., Reker, G. T., \& Gesser, G. (1994). Death attitude profile-revised: A multidimensional measure of attitudes toward death. In R. A. Neimeyer (Ed.), Death anxiety handbook: Research, instrumentation, and application (pp. 121-148). Washington, DC: Taylor \& Francis.

Yüksel, P., \& Yıldırım, S. (2015). Theoretical frameworks, methods, and procedures for conducting phenomenological studies in educational settings. Turkish Online Journal of Qualitative Inquiry, $6(1), 1-20$.

Zangirolami-Raimundo, J., Echeimberg, J. O., \& Leone, C. (2018). Research methodology topics: Cross-sectional studies. Journal of Human Growth and Development, 28(3). 356-360. doi: http://dx.doi.org/10.7322/jhgd.152198.

Zhang, J., Peng, J., Gao, P., Huang, H., Cao, Y., Zheng, L., \& Miao, D. (2019). Relationship between meaning in life and death anxiety in the elderly: Self-esteem as a mediator. BMC Geriatrics, 19(308). https://doi.org/10.1186/s12877-019-1316-7.

Zheng, M. (2015). Conceptualization of cross-sectional mixed methods studies in health science: A methodological review. International Journal of Quantitative and Qualitative Research Methods, 3(2), 66-87. 
